\title{
REASSESSING LATIN PEDAGOGY: A PROPOSED MODEL FOR SOUTH AFRICAN LEARNERS
}

\author{
M Dircksen (North-West University)
}

\begin{abstract}
At present two models of instruction predominate the scene of mainstream $21^{\text {st }}$ century Latin pedagogy. The first, commonly known as the 'philological model' or 'grammar-and-translation' method, has been prevalent since the early days of classical scholarship and still forms the basis of methodology at most South African universities. During the past two decades the second, the so-called 'living language' method, has become popular in schools and universities across the United States. Both methodologies are examined and evaluated in this article. Based on this short overview of Latin pedagogy, a model is then proposed to accommodate generation $\mathrm{Y}$ students of Latin at South African universities utilising both the 'living language' method and the 'flipped class-room' approach. Since the student profile of the North West University has changed dramatically over the past few years to include an ever increasing number of distance students, the challenge has been to accommodate the needs of these students without sacrificing the preferred approach or method. Excerpts taken from a learning management system, ${ }^{1}$ developed for the Oxford Latin Course and aimed at distance students, will finally illustrate how the learning of these students is facilitated. The LMS in question is also aimed at secondary school learners who are keen to follow an online Latin course.
\end{abstract}

\section{Introduction}

Since the $2^{\text {nd }}$ century AD every generation have lamented the decline of classical studies - even during the Renaissance humanists engaged themselves in desperate attempts to save the classics from oblivion (Beard 2011). At present instruction of classical languages is yet again under threat in schools and universities across the world where many departments of classics had to close. The decline of classical studies has been attributed to many factors, varying from the traditional and negative association with imperialism and elitism (Ball \& Ellsworth 1989b:56), to more recent criticism that is aimed at narrow-minded teaching strategies - a condemnation of the 'most mind numbing form of pedagogy' (Beard 2011). Such serious accusations call for radical adjustments to Latin pedagogy - once again to prevent the extinction of Latin in a modern curriculum. In her review

Hereafter referred to as LMS. 
article Beard notes that 'the sense of imminent loss' has had a positive outcome in the sense that it has inspired classicists and given them an 'edginess' to foster the classical tradition. ${ }^{2}$ The review of literature in this article will prove that modern day Latin lecturers and teachers have indeed taken up the challenge and have put innovative new ways of teaching Latin into practice. Their aim is to make the study of Latin not only pleasant but also more viable in a rapidly changing environment.

At the two extremes of the methodology spectrum lie the 'philological model' or 'grammar-and-translation' method and the 'living language' method or 'humanist model'. A short overview of both the 'philological' and the 'living language' methods together with their respective advantages and shortcomings will provide the context for a proposed instructional strategy which incorporates the most valuable elements of present day Latin pedagogy.

\section{The philological or grammar-and-translation method}

The philological method concentrates on the morphology and syntax of Latin, the memorisation of grammatical rules and the eventual reading, or 'meticulous deciphering' (Ball \& Ellsworth 1989b:55; 1996:82) of classical texts in the original. The method had its origin in the $19^{\text {th }}$ century when Latin was no longer spoken and its study was justified as an intellectual discipline to train the mind and expose it to the riches of ancient Latin literature (Ball \& Ellsworth1989b:55). The central objective for secondary and university Latin, based on this traditional method of Latin instruction is often still 'the progressive development of ability to read and understand Latin'. ${ }^{3}$

The main advantages ${ }^{4}$ of this method lie in its contribution to excellent foundations in grammar, English vocabulary and linguistics, and an increased ability to learn foreign languages. ${ }^{5}$ Since Latin has such a precise, fixed and logical structure, a method based on the grammar and syntax of the language may contribute to the development of analytical skills.

The traditional problem associated with this method is the 'large swathes of rote-memorized, poorly understood, and seldom used paradigmatic information'

2 See, however, the cynical remarks of Steve Drummond 2014 concerning Latin's perennial 'comeback'.

3 In 1924 the advisory committee of The American Classical League spelt out these aims in their report (Carpenter 2000:391).

4 Dircksen 2010:125-128 provides a summary of the academic advantages claimed for Latin. On research done in this regard see Holliday 2012:3-12.

5 Not everyone agrees on this point: 'But honestly, if you want to learn French, you'd frankly be better off doing that, not starting with some other language first' (Beard 2011). 
(Carpenter 2000:394-395). The most serious critique that supporters of the living language method level against this method, however, is that students experience the Latin text as a difficult code which they must decipher, rather than a language which naturally expresses meaning (Deagon 1991:60, Gruber-Miller 2005:89). ${ }^{6}$ Taught in this way, Latin is accessible only to students who think well in analytical and abstract ways while there are a number of students who find an analytical discussion of any language very difficult (Deagon 1991:69, Wills 1998:31).

Some authors link the drastic decline in student numbers towards the end of the last century directly to the grammar-and-translation method: 'Unfortunately today's students still study the classical languages primarily from textbooks based on the grammar-translation method, yielding a mortality-rate perhaps unprecedented in any field of study' (Ball \& Ellsworth 1989b:55).

Most lecturers accept that the grammar grind is no longer an appropriate method for today's students who do not have the skills to learn Latin using the 'traditional approach' (Ball \& Ellsworth 1989a:1) and suggest ways in which to adapt instruction, in order to accommodate both the abilities and deficiencies of students. Grammar is spread more evenly, vocabulary can be limited to words with a high frequency of occurrence, the basics of English grammar can be taught before moving on to Latin grammar (Ball \& Ellsworth 1989a:4) and 'composition' can be removed as an outcome (Ball \& Ellsworth 1989a:5-6 and 1989b:54-62). The focus has also lately been more on reading Latin and pattern recognition to reduce the number of inflected forms to be memorised (Ball \& Ellsworth 1989a:4-5). Some still insist on 'real Latin' (Ball \& Ellsworth 1989a:7), while modern graded reading texts such as The Oxford Latin Course which encourages contextual reading and immediate application of newly learned morphological information has become increasingly popular (Carpenter 2000:395). The concerted effort to stimulate contextual reading with understanding and less memorisation and grammar drill, has also led to the return of interlinear translation (Ball \& Ellsworth 1989a:8 and Blum 2008).

\section{The history of the direct or conversational method}

The 'grammar-and-translation' model stands against what Pavur (1998) calls the 'humanist model' or what is more commonly known as the 'direct', or 'natural' method (Wingate 2012).

6 The general principles of the method are based on the traditional grammatical and syntactical catagories of $19^{\text {th }}$ century linguistics when there seems to have been an obsession with the phonological and morphological systems of language with little attention to syntax, semantics and pragmatics (Knudsvig \& Pennel Ross 1998:34). 
This approach is based on a conversational method, and is adopted from modern language techniques (Deagon 1991:59). Ideally all explanations, questions and answers are done in Latin and both lecturer and students speak only Latin in the classroom. Latin is literally brought back to life, which explains why it is generally known as the 'living Latin' method.

It is important to remember that spoken Latin never truly 'died out' after the fall of the Roman Empire. ${ }^{7}$ Apart from the evolvement of Latin into modern Romance languages, Latin survived as a 'second language' in writing, as the language of the church (until the Second Vatican Council in the 1960's), as the learned language for scientific and political affairs and the lingua franca of European merchants. It was still the official language during the Middle Ages and the language of instruction in schools and universities (Cox 2000; Moodie 2014:452). According to Dante, Latin was a language of great prestige as compared to the vernacular (Farrel 2001:16). After the invention of printing by c. 1450 (Moodie 2014:2) three quarters of books were printed in Latin for at least fifty years, and by the end of the sixteenth century more than half the books were still in Latin. Latin remained an international language even for mathematics until the eighteenth century (Moodie 2014:454).

In Europe during the Renaissance lectures and debates were still held in Latin until the mid-seventeenth century and was not replaced by vernaculars until the end of the eighteenth century (Moodie 2014:455, 465). Comenius argued as follows for active learning of Latin in his lanua Linguarum of 1631: Omnis lingua usu potius discitur quam praeceptis, id est, audiendo, legendo, relegendo, imitationem manu et lingua temptando quam creberrume (as quoted by Wills 1998:28): 'Every language is learnt by use rather than by rules, that is by listening, reading, reading again, by trying to imitate with a gesture or word as frequently as possible' (translation my own). The Latin schooling of the Renaissance gives us some indication of the principles on which the adherents of the living language base their methodology. Traces of the oral Latin tradition also transpire in the Statutes of Harvard ( $c a$. 1646) which exacted of its students the ability to 'make and speak true Latin in verse and prose' (Wills 1998:28).

Living Latinity survived during the modern era in ecclesiastical circles ${ }^{8}$ in the form of theses written in Latin and in modern Latin classics such as the work of Descartes, Bacon, Newton, Francis Bacon and Linnaeus (Pavur, Ball \& Ellsworth 1998b:54). In the $20^{\text {th }}$ century Latin oratory still formed the basis of education in Jesuit schools (Wills 1998:28), but it seems that the speaking of Latin

For a bibliography of authors who have undertaken to give histories of the Latin language from ancient Rome to the present, see Coffee 2012:256.

8 The Roman Catholic Church has published the periodical, Latinitas, since 1953. 
has since been bound up with the effort of enthusiasts. One instance is the production by The Finnish Broadcasting Company of Nuntii Latini, a weekly radio news summary in Latin (Farrel 2001:109). The spark which ignited interest in teaching Latin as a living, spoken language in the modern era was provided by a few inspirational individuals. W H D Rouse, Headmaster of the Perse School at Cambridge from 1902 to 1928, first introduced this method into his class room (Stray 2011:5-7; Coffee 2012:256-257), but since there were no skilled teachers to implement his method effectively and assessment of the learners' competence proved difficult, Perse called the experiment off after Rouse's retirement. A postwar movement, the Academia Latinitati Fovendae (ALF) promoted the active use of Latin (Coffee 2012:257). Eichenseer, a Bavarian monk who wrote extensively on proper Latin usage, held his first active Latin summer seminar in Germany in 1973, and in 1985, Father Reginald Foster, an American priest and secretary to the pope in Rome, began to present his Aestiva Romae Latinitas (Coffee 2012:258) in Rome and at the Gregorian University using Latin as a modern language. 'Reginaldus worked a kind of magic. He transformed Latin from a set of puzzles to be solved into something to be known, possessed and loved' (Grafton 2015:28). Now that Foster has retired to Milwaukee some of his former students are perpetuating his legacy. Jason Pedicone and Eric Hewett have started the Paideia Institute, and organise summer programmes in Rome and surrounds where they teach students Latin in the same way they have been taught. Among their institutional members, Paideia counts Brown, Cornell Dartmouth, Harvard and Princeton (Grafton 2015:30) and these universities send their students to study in its programmes. ${ }^{9}$ In the year 2000, Miraglia founded the Academia Vivarium Novum in Italy with a one-year college-level curriculum entirely in Latin and the University of Kentucky similarly offers an MA programme using only Latin as language of instruction (Coffee 2012:261-262). At another level conversational Latin seminars have become very popular with an ever increasing number of participants (cf. Coffee 2012:262). ${ }^{10}$

9 On the state of spoken Latin today and the goals for the use of active Latin see Coffee 2012:256.

10 One of Foster's former students, Nancy Llewellyn, Associate Professor of Latin at Wyoming Catholic College, organises the Rusticatio Virginiana every summer in a beautiful country villa which formerly belonged to a member of the Washington family. After attending this week long total immersion workshop in 2014, I invited Professor Llewellyn to South Africa to present a similar workshop at the North West University. The few South African teachers and students who took part were impressed by this refreshingly new and enjoyable method. To improve their skills, the group has been invited to attend the Rusticatio summer seminar in July 2016. 


\section{Opposition to the living language method}

The opponents of 'oral Latin' regard it as nothing more than humorous transformations such as Henry Beard's Latin for all occasions, and regard it as a trivialising of serious grammatical study. In their 1996 article Ball \& Ellsworth declare the claim of 'endangered Latin teachers' to teach students to speak, hear, write, and read Latin, 'unattainable'. According to them Latin is no longer a language used for communication but merely a written language 'divorced from everyday human interests and activities' (1996:78). The authors are convinced that academic politics, administrative convenience and budgetary constraints have led to a combination of modern and classical languages in the same departments and classicist have thus felt compelled to adopt modern language methodologies however inappropriate they may seem. ${ }^{11}$ They argue that classroom conversations are artificial, that no 'correct' pronunciation of classical Latin exists, and that students spend time on activities that hinder them from learning to translate classical texts with 'rigor and depth'. Wingate (2012) is of the opinion that the method fails because of the difficulty of evaluation and its incompatibility with the generally accepted goals of Latin instruction i.e. training and disciplining the mind, the goal of understanding English grammar more thoroughly, and helping the development of a larger and more nuanced English vocabulary. ${ }^{12}$

\section{Support for the living language method}

Adherents of the living language method list the following positive aspects:

1. The most powerful argument in support of the living language method is that this methodology will engage students of all learning styles. (GruberMiller 2006:16; 2005:87; Deagon 1991:69). Lecturers who support the method find that especially those students who are strong on audial memory and weak on analysis benefit from hearing, speaking and reading Latin as often as possible (Abbot \& Davis:1996; Wills 1998:28).

2. Listening and speaking offer students a way to understand the classical authors as writers to be heard and performed. Students 'become more comfortable with the rhythms, sounds, and verbal patterns in Plautus'

11 For more information on Latin's status as a 'foreign language' and its fulfillment of requirements set by the American Council on the Teaching of Foreign Languages see Wills 1998:27.

12 See also Carpenter 2000:392 who sees no practical application for writing or speaking Latin and Beard 2011 who argues that the only good reason for learning Latin, is to read what is written in it. 
wordplays, Catullus' meters, Cicero's arguments, and Petronius' narratives' (Gruber-Miller 2005:88).

3. Proficiency in oral activities also develops reading and writing skills and reinforces vocabulary, grammar and syntax (Gruber-Miller 2005:88).

4. Since students convey messages and respond to these messages, the method encourages a sense of community (Gruber-Miller 2006:17).

5. The method delivers a linguistic purpose fit for the $21^{\text {st }}$ century as it is better adapted to the learning and social needs of today's student. Our generation $\mathrm{X}^{13}$ and $\mathrm{Y}^{14}$ students want to express themselves. They get bored easily with the 'talking head' of the lecturer (Rapport 30 March 2008 NUUS III), they want to be engaged in what happens in the class room and demand a dynamic class environment where all senses are stimulated and information is given and absorbed at a fast pace (Abbot \& Davis 1996:86). The vigour and energy which a variety of activities and group work, games, visuals and songs bring to the class room, all contribute to the 'fun element' which is the best recipe for successful language learning (Wills 1998:32; Deagon 1991:69).

6. Students experience the speaking and hearing of Latin as much more meaningful (Deagon 1991:60) since they are making that essential connection between past and present (Abbott \& Davis 1996:85).

7. The living Latin method presents all students, whatever the quality of their secondary education, with an equal chance of excelling at Latin. It seems to be a universal phenomenon that students enter university with hardly any knowledge of grammar,,$^{15}$ but since the Living Latin method is based on an instinctive understanding of what certain phrases mean and grammar exercises are done in an informal and incidental way, this broadens the appeal to a wider audience (Deagon 1991:63).

8. The final and perhaps most convincing argument in favour of the living language method is the fact that spoken Latin is simply more popular

13 This refers to the generation born after that of the baby boomers (roughly from the early 1960s to mid 1970s), typically perceived to be disaffected and directionless. $\mathrm{http} / / /$ socialmarketing.org/archives/generations-xy-z-and-the-others/(2016/06/14)

14 This refers to the generation born in the 1980s and 1990s, comprising primarily the children of the baby boomers and typically perceived as increasingly familiar with digital and electronic technology. http://socialmarketing.org/archives/generations-xy-zand-the-others/(2016/06/14).

15 See Ball \& Ellsworth 1989a:1 who describe the situation amongst students in Hawaii. 
with students (Sienkwitcz et al 1999:62, Wills 1998:33). 'Though we hope to bring them to the point of solitary appreciation of Latin literature, we will get more of them to that point if we make the journey more exciting' (Deagon 1991:69). In general it is fair to say that there is a rising interest in 'oral' or 'active' Latin and that teachers are experimenting with this kind of instruction (Wills 1998:27; Coffee 2012; Sienkewicz et al. 1999).

\section{A proposed model for South African universities}

The advantages of adopting the living Latin method over the grammar-andtranslation method are clear. The successful implementation of the method in the USA where student numbers have increased significantly provides further motivation. ${ }^{16}$

In South Africa the method is being implemented at North West University where it is used in combination with the Oxford Latin Course. ${ }^{17}$ The Oxford Latin Course has been chosen for the first year course since it is based on the inductive approach which implies that grammar is peripheral and that the aim is to read simple Latin texts. These features make it ideally suitable for any lecturer to implement the living language method. Every chapter of the Oxford Latin Course introduces new material with a cartoon strip accompanied by Latin sub titles. It is easy for students to guess what the Latin sentences mean by looking at the pictures or if they really get stuck, to refer to the vocabulary on the next page. A Latin passage which contains the chapter's vocabulary and newly introduced grammar completes the reading component of the chapter. Grammatical explanations, verb exercises and sentences for translations appear separately, at the back of the book. This arrangement of material makes it very convenient for both lecturer and student to incorporate as much or as little of the traditional grammar translation method as he or she chooses.

Since students from colleges throughout South Africa who are affiliated to the Faculty of Theology have to be accommodated, the method of delivery had to be adapted to meet the challenge of distance learning. White board technology is employed to deliver one (recorded) lecture per week. Most of the learning is done online by means of exercises and tasks. ${ }^{18}$ According to Moodie (2014:467) online

16 In June 2016 I attended a conference of the Americal Classical League where more than 300 teachers of Latin at secondary schools and university lecturers were present.

17 Gruber-Miller 2005 shares many examples of how to incorporate oral skills when using the Oxford Latin Course.

18 On a communicative approach in teaching languages using whiteboard technology see Schmid \& Whyte 2014:1-19. 
learning is a considerable advance on open learning by print and post, but thus far it is an advance in transmitting information, not teaching it. ${ }^{19}$ To address this problem and to accommodate the 'living language' method a LMS for Latin 1 (beginners) has been developed by lecturers from North West University which adapts the TLBT (task-based language teaching) method to accommodate CLT (communicative language teaching) (Schmid \& Whyte 2014:5-6) by adding sound clips.

The addendum to this article contains images copied from this LMS. Based on the Oxford Latin Course, it is an attempt to meet the pedagogical challenge of providing distance students with a living language experience. It contains a page entitled 'Module information' where very explicit directions are provided on how to work through every chapter (How to study). The page entitled 'Module content' provides the expected outcomes for the specific chapter, the translations of all exercises in the chapter, a soundtrack, enrichment exercises, tests and the Microsoft Power Point presentation which was used during the contact lecture and a comprehension test. The comprehension test based on the passage on p.10 of the Oxford Latin Course provides a good example of how any passage can be utilised to practise audio skills. The meaning of the interrogatives cur, ubi, quis, quomodo and quando are provided, and students then listen to an audio clip which contains questions on the passage (Cur Scintilla fessa est? Quis casam intrat? etc.) Students then provide answers in Latin which will be checked in class or, if they are distance students, written answers are sent via email.

The platform is used by both distance and full time students ${ }^{20}$ while interested learners from local secondary schools (where Latin is no longer taught) are also linked to the site.

\section{Conclusion}

The grammar-and-translation method with its heavy reliance on memorisation and rote learning and eventual decoding of texts is no longer suitable for generation $\mathrm{X}$ and $\mathrm{Y}$ students of the $21^{\text {st }}$ century. Taught in this way, they find Latin difficult, time consuming and boring. Latin has made a remarkable turnaround in American secondary schools - a turnaround attributed mainly to the modification of outdated teaching methodologies. ${ }^{21}$

19 Moodie 2014:450-451 regards online education as the single biggest change in education since the printing press.

20 A video on the possibilities of online learning is available at: www.youtube.com/watch?v=yn5MkE-djxA

${ }^{21} \mathrm{http} / /$ education.stateuniversity.com/pages/2160/Latin-in-Schools-Teaching.html\#ixzz 4BS7CzrVe (13/06/2016). 
Latin lecturers in South Africa certainly need new strategies that will guarantee their subject the place it merits. Although very few students major in Latin many take it as an 'extra' subject. Lecturers need to accommodate these students who are able to make allowance for an additional subject. In the present day technologically advanced era students in general prefer to work online - an attractive benefit of the so called 'flipped classroom' learning style. The proposed model, as set out above, is delivered online, and includes built-in features of the LMS such as 'tests and quizzes'. Links are also provided to more exercises with memos and a Power Point presentation with oral exercises and sound clips which enables the student to experience Latin instruction hands-on. The student progresses at his or her own pace and the lecturer assumes the role of facilitator.

Since Latin has been all but phased out from secondary schools in the country it is also the concern of university lecturers to devise a similar strategy aimed at learners who are interested in Latin instruction. By providing these learners with access to the LMS, the need for Latin tuition at secondary school level is also addressed.

The time has come to embrace advances in both methodology and technology to facilitate the resurgence of Latin - an ancient language, present and exuberant in $21^{\text {st }}$ century classrooms.

\section{Addendum (Extract from page entitled 'Module Information')}

\section{How to study}

Follow these steps when you prepare or revise a chapter from the Oxford Latin Course (OLC):

1. Read the cartoon captions aloud. Compare the Latin with the English translation which you will find under 'Module Content; Chapter 1'. Make sure that you know what every Latin word means.

2. Read all the notes and explanations which you will find in the OLC (Balme \& Morwood, 1996:108 and further) so that you understand everything about the text (it is not necessary to memorise anything).

3. Read the sentences aloud again until you understand without looking at the English translation.

4. Listen to the oral recording of the Latin text (as often as you can) while understanding what the text means. 
5. Follow steps 1 to 4 to master the Latin text which follows the cartoons and the exercises (e.g. p. 108: Exercise 1.1, 1.2 and 1.3) which are based on the content of the chapter.

6. Make notes of any questions you may have so that we can discuss these in class.

The following is an extract from the 'Module Content' page.

Module content

Chapter 1

\section{Learning outcomes}

After completing this Chapter you should be able to:

* understand simple Latin sentences consisting of a subject and an active verb in the present tense

* understand simple Latin sentences consisting of a subject, the verb est and a complement

* give the meaning of all Latin words used in chapter 1 of your prescribed book

* give a cursory survey of the life, career and works of Quintus Horatius Flaccus

\section{Note:}

i The Latin verb often comes at the end of the sentence.

ii Latin has no definite (the) or indefinite article (a)

iii Latin does not always express the object. The verb ending shows the subject: laborat $=$ he/she works

iv laborat $=$ he works OR he is working

\section{ANSWERS: CHAPTER 1}

answch1.docx (this link provides access to a document which contains all the translations of the cartoon captions, passages, and sentences relating to the chapter).

SOUND TRACK:

Here are some links on which you can click to listen to the Latin cartoon captions and the passage (p.10). Listen to it repeatedly while you think of the meaning. 
Chapter 1 vocab.mp3

Chapter 1.mp3

Chapter1 passage.mp3

\section{* VERRYKING/ENRICHMENT}

www.umsl.edu/ $\sim$ phillipsm/oldrills/

Test Chapter 1.doc

Test Chapter 1memo.doc

Now complete class test 1 under Tests \& Quizzes to earn your first participation mark

Below you will find the link to the Power Point on Chapter 1

The Power Point contains assignments, exercises and audio material

The Microsoft Power Point link takes the student to exercises which make use of sound clips. The following three slides are provided as illustration.

The first is a vocabulary drill where students look at the pictures, give the Latin word to describe the picture and then listen to the recording to check their answers.
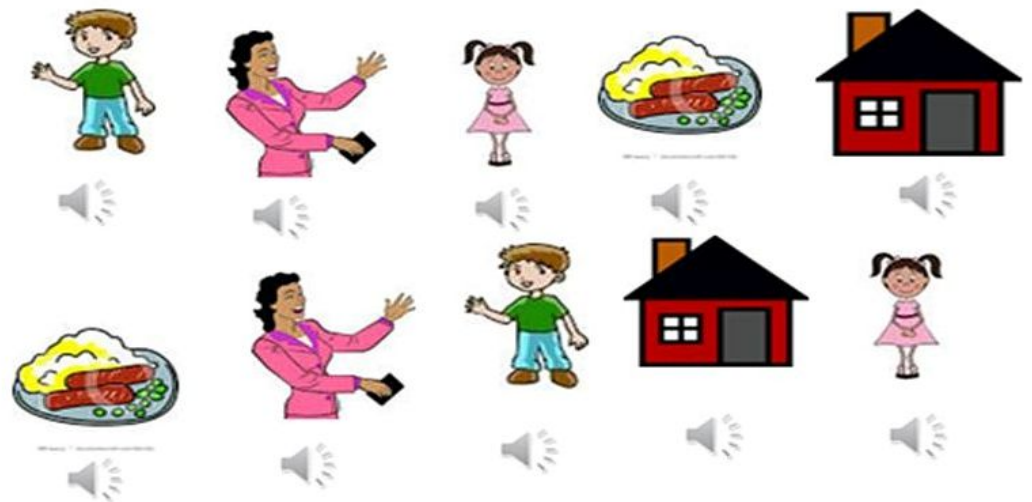
In the second slide a noun is joined to a verb e.g. femina festinat. The sound clip provides the correct answer so that the student can check her answer.

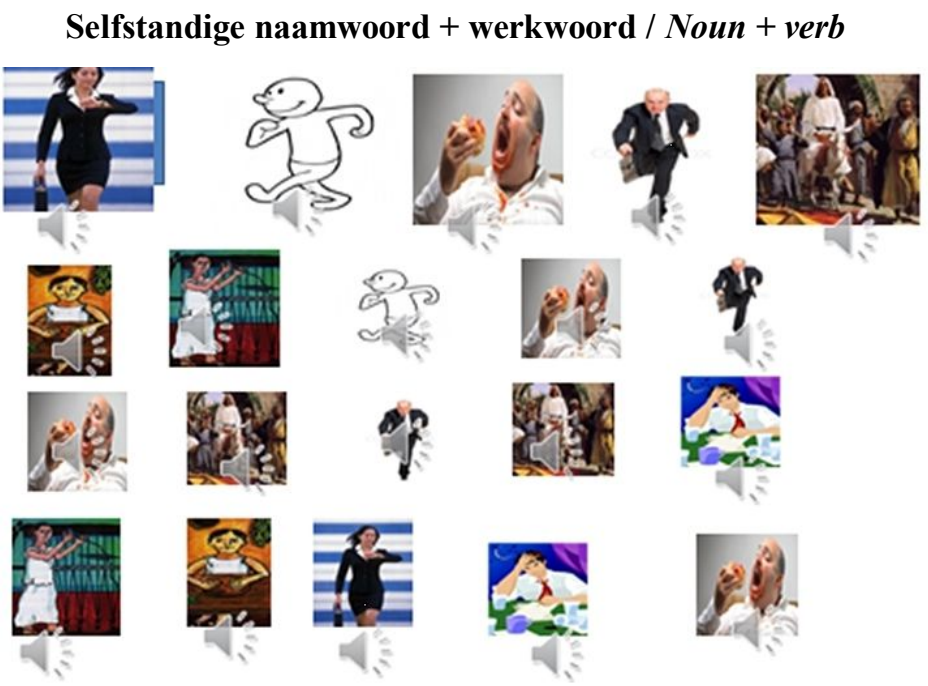

In the third slide a subject is joined to a complement, (adjective) by using 'est'. Students attempt to give a description of the picture in Latin before listening to the audio clip. The description is given in the audio clip (e.g. femina parata est); except for the second but last picture. The student is asked to use 'voice note' on 'WhatsApp' to record a caption for this picture and send it to the lecturer's phone.

$$
\text { Onderwerp + b.nw. + est / Subject + adjective + est }
$$

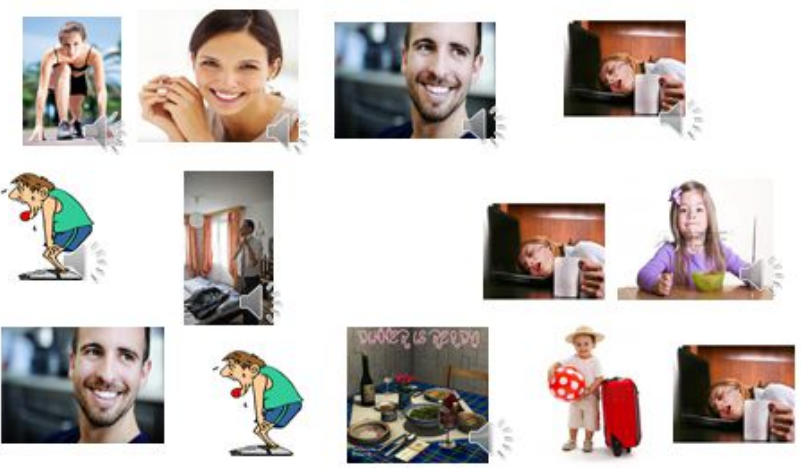




\section{LISTENING COMPETENCY}

Use the following interrogatives to answer the questions you will hear in the sound clips (1-4). The questions are based on the passage on p. 10 of the OLC. Answer in Latin.
Ubi $=$ where?
Cur $=$ why?
Quis $=$ who
Quomodo = how?
Quando? $=$ When
1. (cur Scintilla fessa est?)
2. (quis in casam intrat?)
3. (ubi Horatia laborat?)
4. (quando Scintilla ad tabernas ambulat?)

\section{BIBLIOGRAPHY}

Abbott, M G \& Davis, S 1996. Hyperreality and the study of Latin: Living in a fairy tale world. The Modern Language Journal 80.1:85-86.

Ball, R J \& Ellsworth, J D 1989a. Teaching classical languages: A reasonable approach. Classical World 83.1:1-12.

Ball, R J \& Ellsworth J D 1989b. Against teaching composition in classical languages. The Classical Journal 85.1:54-62.

Ball, R J \& Ellsworth, J D 1996. The emperor's new clothes: Hyperreality and the study of Latin. The Modern Language Journal 80.1:77-84.

Beard, M 2012. Do the classics have a future?_The New York Review of Books 12 January. Accessed from: www.nybooks.com/articles/2012/01/12do-classicshave-future/ [15 January 2016].

Blum, E 2008. The new old way of learning languages. The American Scholar: 180-88. Accessed from https://theamericanscholar.org/the-new-old-way-oflearning-languages/\#.VpouoVLdW (16/01/2016).

Carpenter, D 2000. Reassessing the goal of Latin pedagogy. The Classical Journal 95.4:391-395.

Coffee, N 2012. Active Latin: Quo tendimus? Classical World 105.2:255-269.

Cox, N 2000. Medieval education. In Academical dress in New Zealand. (2016/01/18).

http://www.academicapparel.com/caps/History-College-Education.html

Deagon, A W 1991. Learning process and exercise sequencing in Latin instruction. Classical Journal 87:59-70. 
Dictionary of medieval Latin from British sources 2012. Available from: http://www.dmlbs.ox.ac.uk/british-medieval-latin/language

Dircksen, M R 2010. Latyn en die opleiding van regstudente in Suid-Afrika: 'n Nuwe relevansie. De Iure 43.1:117-128.

Drummond, S 2014. Is Latin making a comeback in Schools? Caveat lector (2016.10.16). http://www.npr.org/sections/ed/2014/06/30/325537674/islatin-making-a-comeback-in-schools-caveat-lector

Farrel, J 2001. Latin language and Latin culture from ancient to modern times. Cambridge University Press: Cambridge.

Grafton, A 2015. Latin Lives: 27-31. The Nation. Books \& the Arts 16 February.

Gruber-Miller, J 2005. Developing listening and speaking skills: Practical ways to implement the standards with the Oxford Latin course. The Classical Journal 101.1:87-98.

Gruber-Miller, J 2006. Communication, context, and community: Integrating the standards in the Greek and Latin classroom. In Gruber-Miller, J (ed.) When dead tongues speak: Teaching beginning Greek and Latin. Oxford: Oxford University Press.

Holliday, L R 2012. The benefits of Latin? Educational Research Quarterly 36.1:3-12.

Knudsvig, G M, \& Pennell-Ross, D 1998. The linguistic perspective. In LaFleur, R A (ed.) Latin for the $21^{\text {st }}$ century: From concept to classroom. Glenview IL: Scotts Foresman-Addison Wesley: 25-35.

Moodie, G 2014. Gutenberg's effects on universities. History of education 43.4:450-467 (2016/04/30).

http://dx.doi.org/10.1080/0046760X.2014.93018

Pavur, C 1998. Upgrading Latin pedagogy. Electronic Antiquity 4:2. (2016/04/01) https://scholar.lib.vt.edu/ejournals/ElAnt/V4N2/pavur.html

Philips, F C 1988. The language laboratory and the teaching of 'dead' languages. $C W$ 82:105-108.

Schmid, E U \& Whyte, S (ed.) 2014. Teaching languages with technology: Communicative approaches to interactive whiteboard use: A resource book for teacher development. London, New York: Bloomsbury Academic.

Sienkewicz, T J, Genung, D, Ihlendorf, C, Robertson, C, 1999. Latin teaching standards. The Classical Journal 95.1:55-63.

Stray, C 2011. Success and failure: W H D Rouse and direct-method classics teaching in Edwardian England. Journal of Classics Teaching 22:5-7.

Wills, J 1998. Speaking Latin in schools and colleges. $C W$ 92:27-34.

Wingate, H 2012. The history of the natural method of teaching Latin. http://www.memoriapress.com/articles/history-natural-method-teachinglatin-part-ii (2016/05/01). 